\title{
Multicultural London English / Multicultural Paris French.
}

Implications for the classroom

Raymonde Sneddon

\section{(2) OpenEdition}

\section{Journals}

Electronic version

URL: http://journals.openedition.org/esp/662

DOI: $10.4000 /$ esp.662

ISSN: 2532-0319

\section{Publisher}

Centre d'Information sur l'Éducation Bilingue et Plurilingue

Printed version

Date of publication: 1 December 2015

Number of pages: $79-88$

ISSN: 1127-266X

\section{Electronic reference}

Raymonde Sneddon, « Multicultural London English / Multicultural Paris French. », Éducation et sociétés plurilingues [Online], 39 | 2015, Online since 01 October 2016, connection on 10 December 2020. URL : http://journals.openedition.org/esp/662 ; DOI : https://doi.org/10.4000/esp.662 


\section{MULTICULTURAL LONDON ENGLISH / MULTICULTURAL PARIS FRENCH. IMPLICATIONS FOR THE GLASSROOM}

\section{Raymonde SNEDDON}

Le projet Multicultural London English /Multicultural Paris French (http://wrww.mlempf.bbk.ac.uk) fut lancé en 2010 à Birkbeck, University of London. Les données ont été recueillies auprès de jeunes dans divers lieux des banlieues parisiennes, puis comparées à celles réunies lors d'un projet antérieur sur l'anglais multiculturel de Londres. MLE/MPF est la première comparaison à grande échelle du langage informel employé par des jeunes dans deux contextes significatifs de l'Europe occidentale. Cet article décrit les principales conclusions de la recherche par rapport aux marqueurs pragmatiques, traits syntactiques, éléments de vocabulaire et de phonologie. Il inclut les ressources développées par le projet afin de servir dans la salle de classe pour aider les élèves dans leur recherche, leurs enquêtes inter-linguistiques et la créativité langagière.

Mots-clés: langues des jeunes; français multiculturel de Paris; anglais multiculturel de Londres; marqueurs pragmatiques; traits syntactiques; vocabulaire; phonologie

Il progetto Multicultural London English /Multicultural Paris French (http://www.mlempf.bbk.ac.uk) è stato lanciato nel 2010 a Birkbeck, University of London. I dati sono stati raccolti presso giovani in vari luoghi delle periferie parigine e, in seguito, paragonati a quelli raccolti nel corso di un precedente progetto sull'inglese multiculturale di Londra. MLE / MPF rappresenta il primo confronto su larga scala del linguaggio informale, utilizzato da giovani in due contesti significativi dell'Europa occidentale. Questo articolo descrive le principali conclusioni della ricerca in relazione a marcatori pragmatici, a caratteristiche sintattiche, a elementi di vocabolario e fonologia. Il testo presenta le risorse, sviluppate dal progetto, da utilizzare in classe per aiutare gli studenti nella loro ricerca, nelle loro indagini inter-linguistiche e nella creatività linguistica.

Parole chiave: lingue della gioventù; francese multiculturale di Parigi; inglese multiculturale di Londra; marcatori pragmatici; caratteristiche sintattiche; vocabolario; fonologia

\section{EXPLORING \\ INFORMAL \\ LANGUAGE \\ IN EAST LONDON}

I n a very successful girls' school in east London the 16 year-old pupils in a General Certificate of Education (GCSE) class are talking about how useful it would be to learn more about the informal language used by their peers in Paris, so that, when they meet, "we know if they are making fun of us, or insulting us". They are also concerned about the impression they will make when they speak: "will they think we are stuffy up because of the way we are talking?" In a neighbouring mixed school the 14 year-old pupils in Year 9 are exploring rap lyrics from a French song (Ma Direction). Working in 
Multicultural London English / Multicultural Paris French. Implications for the classroom

R. SNEDDON
MULTICULTURAL LONDON ENGLISH / MULTICULTURAL PARIS FRENCH small groups they are deeply absorbed in a complex cross-linguistic negotiation of meaning. Through internet research and sharing knowledge and experience they are exploring what a French expression like kiffer means in standard French; what it means in Standard English; and then the most complex task of all: what would be an equivalent expression in English in the given context. They then move on to creating and performing scenarios, poems and raps. What is most striking is the pupils' very high level of motivation and engagement, noted during observations of classroom work in two schools in east London and discussion with pupils on the topic of young people's informal speech. As well as relating to youth culture, pupils' personal experience, and making use of topics of interest, some of the tasks presented offered considerable cognitive challenge. Pupils engaged with concepts of personal and group identity and how they position themselves and each other with respect to multi-level dimensions of categorisation: gendered, ethnic/cultural, social/stylistic/geographical attitudes and values.

As professional translators working with young people know (Translation Nation 2014), understanding and translating informal language and slang require substantial research and discussion around cultural differences and result in a deeper understanding of the social context of language use.

Like the teachers of the Year 9 classes mentioned above, many teachers of French make creative use of film (La Haine), music, literature (Kiffe-kiffe demain) and internet resources to offer opportunities to explore authentic informal language.

For teachers, researchers and for pupils, the Multicultural London English /Multicultural Paris French (MLE/MPF) project offers a fascinating insight into the ways in which language change is led by young people in urban settings.

From 2007 to 2010 a research team led by Paul Kerswill, now at York University, and Jenny Cheshire at Queen Mary, University of London, investigated the role of young people as "linguistic innovators" (Cheshire et al. 2011) and of London as a motor of language change. The Linguistic Innovators research project studied the speech of young people in informal settings in both inner (Hackney) and outer (Havering) London areas, and the subsequent Multicultural London English (MLE) project investigated the extent to which innovations in inner London were becoming established in London speech.

The Multicultural London English / Multicultural Paris French (MLE/MPF) project was launched in 2010, led by Penelope Gardner- 
Multicultural London English / Multicultural Paris French. Implications for the classroom

R. SNEDDON

\section{KEY FINDINGS}

Chloros from Birkbeck, University of London, with Jenny Cheshire from QMUL as co-investigator, and funded by the Economic and Social Research Council (ESRC). It is the first large scale comparison of two significant Western European settings from a sociolinguistic perspective (1). Building on the findings from the London project, the lead MLE/MPF researcher, Maria Secova, collected similar data from young people in a range of locations in various banlieues of Paris. Areas were chosen that had substantial migrant populations. The research team paid particular attention to the influence on French of varieties spoken by communities of immigrant origin, especially French Caribbeans and Maghrebians. A significant part of the data analysis is focused on comparing data from both cities with a view to identifying processes of language contact and patterns of language variation and change.

While innovations based on the speech of multicultural young people arise in both cities, their spread and distribution follows different patterns and we did not find evidence that a variety which one could call Multicultural Paris French is crossing ethnic and social divides in the same way as in London.

This conclusion is supported by specific comparisons between English and French, focusing on key discourse features such as quotatives, general extenders and discourse markers, vocabulary, syntactic features and phonology.

"Quotatives" (introducteurs) are used to introduce direct speech in spoken language (crier, raconter, répondre, demander, répéter). While the words reported by the speaker rarely represent exactly what was actually said, the use of direct speech adds drama and authenticity to the exchange (Fox 2012). The MPF study explores new trends in young people's use of direct speech and compares them with English forms in current use (Secova 2015) as, for ex:

- apres mes frères, ils étaient là "mais non maman laisse la" et tout moi jétais là (imitation pleurs).

- he was describing him and I was like "oh my god you like the same guy as me".

«General extenders» (particules d'extension) are expressions like et tout çananana - etcetera - les/des trucs comme ça, which occur at the end of phrases. While these words often indicate that what is referred to is part of a set, they can be used in informal discourse to be purposefully vague as well as to create solidarity between speakers on the basis of shared knowledge (Spoken English Features, http://linguistics.sllf.qmul.ac.uk/english-language-teaching).

A number of different extenders are in use in the MPF data, but the 
Multicultural London English / Multicultural Paris French. Implications for the classroom

R. SNEDDON
SYNTACTIC FEATURES quantitative analysis indicates that et tout, at $66 \%$, is by far the most common expression in use (cf. and stuff in English).

From her data, Secova (2014) suggests that et tout may have a range of functions, and sometimes several at once:

- "punctor" (individual narrative / quoted speech): "elle reprenait des expressions en fait ... que que j’utilisais et tout... et genre elle s'habillait pareil et tout".

- "hedge" (condenses discourse, avoiding unnecessary detail): "ma mère elle adore euh ... rencontrer des gens que je connais et tout".

- "marker of contrast" (et tout + mais adds justification): "enfin j'avais quelqu'un qui pensait à moi et donc on parlait et tout mais... quand, quand tu comptes que sur toi-même c'est pas facile".

- "intensifier" (if uttered with emphasis): "tu nous bien fais rigoler et tout!"

(Secova, 2014)

"Discourse markers" (marqueurs pragmatiques) are the signposts of discourse and are also frequently used for hedging, for ex.: c'est genre, un truc genre ("donc au final ça devient un truc genre trop swag c'est genre trop cool trop branché trop fun"), style ("ou style quand elle quand elle bougeait et que tout le fil sortait on re- on refermait avec un crayon là"), en mode, façon ("y en a un il est interdit de stade ou un truc façon comme aç"). There are striking differences between the discourse markers used by young people and by older speakers (from Spoken English Features)

Secova (2013a) identifies the following functions for genre: approximation (similar to environ or à peu près), exemplification and paraphrase, quotation (faire genre), irony, focus marker ("les garçons on va dire ... populaires ... c'est genre ceux qui sortent avec les filles et tout), to frame a topic. She notes the similarities in the MPF data in the way that genre and like are used:

- it’s like me yeah... I always just...I can just do weights for hours and like.

- ils se reconnaissent depuis qu'ils ont genre deux ans.

- on dirait des gamins genre "non j’ai pas deux ans!"

- if I just said I'm from round the corner (.) like "I live in this estate here."

The following features were identified in the Paris data:

changes to the indirect interrogative (post verb: je sais ça veut dire quoi, replacing the formal pre-verb: je sais ce que ça veut dire)

- changes to relatives: omission of que, que replacing dont (la fille que vous parlez,

- omission of conjunction (je crois il va venir)

- shortening of adverbs (direct for directement, normal for normalement) 
Multicultural London English / Multicultural Paris French. Implications for the classroom

R. SNEDDON

VOCABULARY

\section{PHONOLOGY}

- simplification of plurals in -al (normals, specials)

The data on syntactic features have been analysed quantitatively in relation to social factors that may impact on young people's language use: gender, age groups defined as 10-13, 14-16 and 17-19, whether they are monolingual or active or passive bilinguals; whether they describe themselves as Franco-French, of mixed parentage, or are the children of foreign-born parents of the same ethnicity; the percentage of friends of different ethnic backgrounds in their social network (Secova 2014).

The greatest users of the features described above are males, aged between 14 and 16, are active bilinguals, have foreign born parents of the same ethnicity and whose networks include $80 \%$ of friends from a different ethnic group.

Vocabulary innovation features prominently in the MLE/MPF database. It offers examples of how colloquial speech, slang, Verlan (the secret back-to-front language that has long been in use by young people) are used to denote peer-based hierarchies, social class (les populaires/popular v les bolosses/losers), styles of clothing (les swag/stylish), common interests (les cybers/popular on social media) and group-specific behaviour (les boug'zeers, les wesh/ghetto boys, les racailles/scum, les caillera/Verlan for racailles), gender issues (les tchoins/slags v les filles hlel (halal)/good girls). It is rich in argot (thune/money, crari/krari/like) and borrowed words: from Arabic (seum/to hate, to be gutted, zehef/annoy, wallah (I swear to God), starfoullah (may God forgive me), from English (speedé, cool, swag, LOL, follow), and from Romani (bedav/majijuana users, bicrav/dealers, marav/to hit, fight, narvalo/idiot).

The data on phonology from the MPF are still in the process of analysis at the time of writing but the following conclusions can already be made. MPF phonology shows numerous consonantal and vocalic features that are typical of unscripted spoken French across many different social, ethnic, and dialect groups in European French. Two such features are:

- word-final consonant cluster reduction (omission of /R/ in Regarde! 'Look!' and /D/ in comprendre 'to understand')

- elision of high vowels in function word reduction (t'sais for tu sais 'you know' and d'ja for déjà 'already')

-Torgersen \& Fagyal 2015

Features that have most likely emerged and/or were amplified in contact with other languages in the Parisian urban areas are:

- palatalization / affrication of word-initial stop consonants (direct 
Multicultural London English / Multicultural Paris French. Implications for the classroom

R. SNEDDON

\section{TEACHING RESOURCES}

'straight', parti 'left')

- tensing of lax front vowels in open syllables (é for è in words such as vrai 'right')

- shortening of unstressed syllables in plurisyllabic words

- accent on the penultimate syllable

-Fagyal 2014

The status of some of the MPF phonological features has been the subject of considerable debate in the research literature. Palatalization and affrication, for instance, tends to be regarded as a non-standard feature while also reported to be wide-spread across many different speech styles in the media and everyday spoken French (Trimaille et al. 2012, Candea et al. 2013). More perception experiments are needed to gauge the precise social significance of MPF phonology for native speakers and learners of French.

Teaching resources have been developed from the 45 hours of recordings made with young people in Paris, as well as material recorded in London by the original MLE project. They are aimed at teachers of French from Year 9 up to A-Level interested in introducing their pupils to authentic contemporary spoken French and to exploring the effect of language contact on patterns of language variation and change. They are designed to complement the resources developed for the Multicultural London English project that are available on the Queen Mary website (http://linguistics.sllf.qmul.ac.uk/english-language-teaching) and follow a similar format.

The teachers of the classes mentioned at the start of this article were enthusiastic about the opportunities offered by the MLE/MPF project for promoting pupil research, both in the classroom and in a homework context. They were also impressed by pupils' enthusiasm for a topic that enabled them to make use of their personal language resources in the classroom. Teachers also raised the issue of the potential for collaboration in school between the English and French departments, given the very interesting relationship between the style and function of the expressions used by young people in London and Paris.

The Activity Files based on the features described in the section above offer an opportunity to explore issues around the topics in the classroom. They include transcripts from London (MLE) and Paris. The activity files and associated audio files can be downloaded from the MLE/MPF website at http://www.mlempf.bbk.ac.uk/Resources.html ). The Activity Files are also available on the website in Power Point format. 
Multicultural London English / Multicultural Paris French. Implications for the classroom

R. SNEDDON
THE RAINCY QUESTIONNAIRE
Each activity file includes a description and examples of the key language features, transcripts and audio files and a range of activities that include personal research, data analysis and drama and writing. Three activity files (Dans le métro/ histoire bus - le Blédard - les boug'zeers) offer opportunities to explore vocabulary and sentence structure in their social context. The three files focused on discourse features offer pupils opportunities to compare examples from the MLE and MPF databases, for example the file on extenders/particules d'extension.

\begin{tabular}{|c|c|}
\hline London English & Paris French \\
\hline Sound file & Sound file \\
\hline 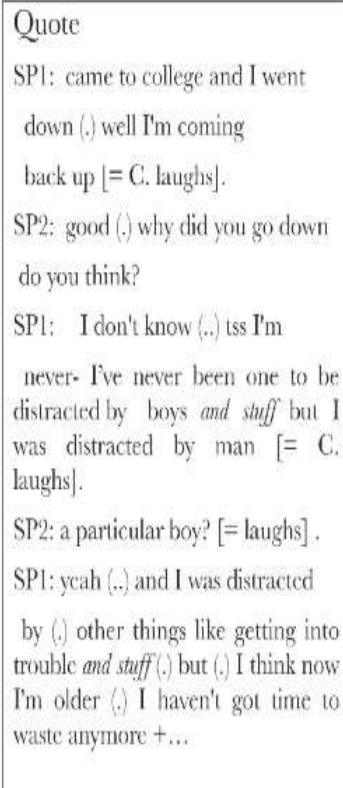 & 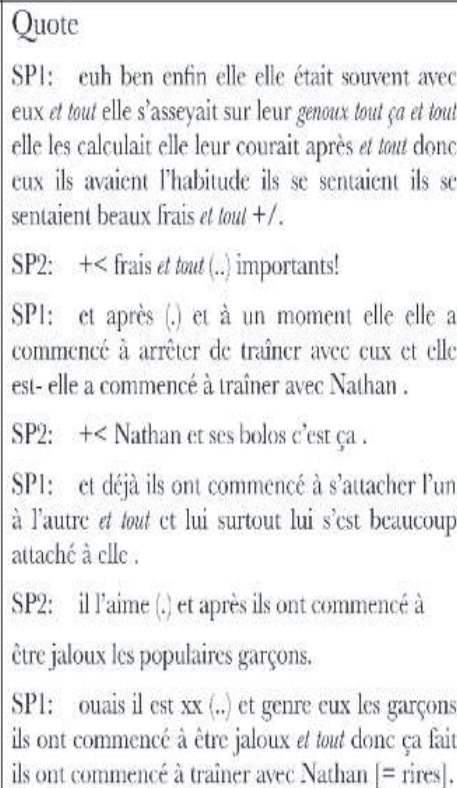 \\
\hline
\end{tabular}

In 2013 students in a class in the Paris suburb of Le Raincy completed a questionnaire about their personal language use in informal contexts. They were offered a range of quotes from MLE/MPF recorded data and for each were asked to indicate their personal use of the expression, as in the following example: 


\section{UTILISERIEZ-VOUS \\ UNE TELLE PHRASE? \\ COCHEZ PLUSIEURS \\ CASES LE CAS \\ ÉCHÉANT:}

CHOOSE A QUOTE

FROM THE

SELECTION

AND CONSIDER

THE FOLLOWING

QUESTIONS:
1) C'est un bolos.

$\square$ Fréquemment

$\square$ De temps en temps

$\square$ Jamais

$\square$ A l'écrit comme à l'oral

Autre commentaire? $\square$ Avec tout le monde, adultes ou jeunes

$\square$ Uniquement en famille ou entre ami(e)s

$\square$ Uniquement entre ami(e)s

$\square$ Uniquement à l'oral

-Secova, 2013

The questionnaire promoted lively discussion about language use in context and attitudes to informal language and resulted in many pupils carrying out their own research into the language use of their friends and family. An activity for students in English schools has been designed based on the questionnaire:

C'est un bolos - Fe crois il veut venir avec nous - Fe vois pas c'est qui - il s'habille bien il a du swag-je suis méga malade

a) What does it mean?

b) In what way does this sentence differ from what you have learnt of French grammar?

c) Who do you think might use this example? In what circumstances and who with?

d) Can you think of an English equivalent (with a similar function)?

-Sneddon, 2014

The resources offer teachers and students original research materials as an addition to film, music and other media resources available on the internet and encourage students to carry out their own research, both with their family and peers and online. The activity files enable students to encounter unfamiliar accents and intonations, to become familiar with some of the discourse-pragmatic features that are common in informal speech and some of the vocabulary used by young people in the Paris area. They offer opportunities for young people to engage with the complex linguistic and cultural task of comparing informal languages and finding equivalent words and expressions.

\section{A DIALOGUE BETWEEN LANGUAGES?}

In dissemination seminars for the MLE/MPF project in May and June 2014, some teachers highlighted the difficulty, however great their interest in the material, of making time in a busy schedule for classroom explorations of material that is not a priority in the language curriculum. Teachers in France, furthermore, claimed to be hamstrung by a rigid syllabus which did not allow time for innovatory activities, especially at the oral level. Given this situation, it was suggested that the materials could best be used, at least in English schools, as part of special awareness of languages projects, involving the English as well as the French department. These would offer a frame- 
Multicultural London English / Multicultural Paris French. Implications for the classroom

R. SNEDDON work for developing high-level metalinguistic skills through motivating and creative cross-linguistic investigations of language in social context and could be used to foster links between schools in France and Britain.

\section{REFERENCES}

CANDEA M., ADDA-DECKER M. \& LAMEL L. . 2013. Recent evolution of non-standard consonantal variants in French broadcast news, Proceedings of Interspeech, pp. 412-416. https://halshs.archives-ouvertes.fr/halshs-00856290

CHESHIRE J., KERSWILL P., FOX S. \& TORGERSEN E. 2011. Contact, the feature pool and the speech community: the Emergence of Multicultural London English. Fournal of Sociolinguistics 15/2: 151196.

FAGYAL Z., 2014. Phonetic variation and change in Multicultural Paris French. Presentation at the AFLS workshop on 10th December 2014, Birkbeck, University of London.

FOX S. 2012. Reporting Speech: the use of quotatives in spoken language. In: Analysing Spoken English: Resources and Techniques for English Language Teachers. Resource Booklet. University of Salford.

SECOVA M. 2013. Multicultural London English / Multicultural Paris French. Questionnaire Le Raincy. http://www.mlempf.bbk.ac.uk/Resources.html

SECOVA M. 2014 "Je sais et tout mais ..." Might the general extenders in European French be changing? Fournal of French Language Studies, 24 (2): 281-304.

SECOVA M. 2015. Discours direct chez les jeunes: nouvelles structures, nouvelles fonctions. Language et Société, 151 (1): 131-151.

SNEDDON R. 2014. Multicultural London English - Multicultural Paris French: a Resource Booklet.

http://www.mlempf.bbk.ac.uk/Resources_files/MLE $\% 20 \mathrm{MPF} \% 20$ RESOURCE\%20BOOKLET.pdf

Spoken English Features: Queen Mary English Language Teaching Resources Archive - http://linguistics.sllf.qmul.ac.uk/english-language-teaching/spoken-english-features

TORGERSEN E. \& FAGYAL Z., 2015. A comparison of speech rhythm and vowel processes in Multicultural London English and Multicultural Paris French, Sociolinguistics of Globalization conference, Hong-Kong, June 3-6.

Translation Nation. 2014. http://www.stephen-spender.org/translation_nation.html 
Multicultural London English / Multicultural Paris French. Implications for the classroom

R. SNEDDON
TRIMAILLE C., CANDEA M. \& LEHKA-LEMARCHAND I. 2012. Existe-t-il une signification sociale stable et univoque de la palatalisation/affrication en français? Étude sur la perception de variantes non standard [Does palatalisation/affrication possess a stable and straightforward social evaluation in French? Studies on the perception of a non-standard variant], Actes du Congrès Mondial de Linguistique Française, Lyon, 4-6 juillet. https://halshs.archives-ouvertes.fr/halshs00766763

\section{FOOTNOTE}

(1) The initial part of the project was done in collaboration with a team in Paris led by Professor F. Gadet, MoDyCo. UMR 7114, and funded by the French ANR (Agence nationale de la recherché), http://mpfvitrine.modyco.fr 